\title{
Development of Spectral Hazard Map for Indonesia with a Return Period of 2500 Years using Probabilistic Method
}

\author{
Asrurifak, M. ${ }^{1)}$, Irsyam, M. ${ }^{1)}$, Budiono, B. ${ }^{1)}$, Triyoso, W.2), Hendriyawan'2)
}

\begin{abstract}
This study is performed to develop spectral hazard map for Indonesia with a Return Period of 2500 years earthquake. It will be proposed for revision of the Indonesian hazard map in SNI-03-1726-2002 as response to the meeting organized by the Department of Public Works on 27- October-2008 in Jakarta. The meeting has decided to revise the Indonesia hazard map by referring to IBC-2006 where spectral acceleration values at Peak Ground Acceleration/PGA, 0.2 and 1.0 second with a return period of 2500 year will be applied for general buildings. The spectral hazard map was analyzed using total probability method and three dimensional (3-D) source models with recent seismotectonic parameters. Four source models were used in this analysis, namely: shallow background, deep background, fault, and subduction source models. Generally, the results of analysis show the values of PGA with a return period of 2500 years relatively higher 1.2-3.0 times than in SNI-03-1726-2002.
\end{abstract}

Keywords: spectral hazard map, 3-D Source model, total probability, peak ground acceleration.

\section{Introduction}

Currently, Indonesia has three earthquake hazard maps issued by the Department of Public Works. The first map is Peak Ground Acceleration (PGA) map at bedrock for 500 years return period in the Indonesian Earthquake Code, SNI 03-1726-2002 [1]. This hazard map is used for designing general buildings. The second is the hazard maps for designing waterworks (dam). This map was developed by Najoan and published by the Research centre for Waterworks, Department of Public Works [2]. The third map is used for designing bridge and road construction published by the Research Centre for Roads and Bridgeworks [3]. This map is referred to the map developed by Najoan with 50 and 100 years life time of structure or 500 and 1000 years return period of earthquake.

The map for PGA at bedrock in the SNI 03-17262002 (Figure 1e) was developed by averaging values from four seismic hazard maps developed by four different research groups in Indonesia (Figure 1a to 1d). These seismic hazard map were developed using total probability theorem [4] and by applying area sources model (2-dimension model).

1) Faculty of Civil and Environmental Engineering, ITB, Bandung, Indonesia

Email: m_asrurifak@yahoo.com

2) Faculty of Mining and Petroleum Engineering, ITB, Bandung, Indonesia

Note: Discussion is expected before June, 1st 2010, and will be published in the "Civil Engineering Dimension" volume 12, number 2, September 2010.

Received 3 June 2009; revised 30 July 2009; accepted 23 August 2009
This 2-dimension (2-D) model has some limitations in modeling the fault source geometries. Moreover, several great earthquake occurrences in Indonesia in the last two years inquire revision of seismic hazard parameters in SNI 03-1726-2002. These earthquake events must be considered in determining seismic hazard parameters especially maximum credible earthquake magnitude (MCE).

\section{Mayor Tectonic of Indonesia Region.}

Indonesia Region, famous as "supermarket of disaster", is located in a tectonically very complex and very active area. According to Bird et al.[5], this region consists of three large tectonic plates and nine small ones (Figure 2). The plates with different types of movement have created subduction and fault zones which are continuously active [6].

The Australia plate subducts beneath the Eurasian plate along the Java trench. The direction of convergence is normal to the trench South of Java, but oblique to the trench Southwest of Sumatra. It is widely accepted that the oblique subduction of Sumatra is partitioned into normal subduction along the trench and strike-slip along the trench-parallel Sumatran Fault [7] . Further East, the continental part of the Australian plate collides with the Banda arc, resulting in widespread deformation throughout the Banda island-arc. Further complicating the tectonics of East Indonesia, Australian continent also collides with the Pacific oceanic plate, resulting in uplift and extensive faulting on the island of New Guinea. Australia-Pacific convergence is highly oblique and appears to be partitioned into components perpendicular and parallel to the margin. 


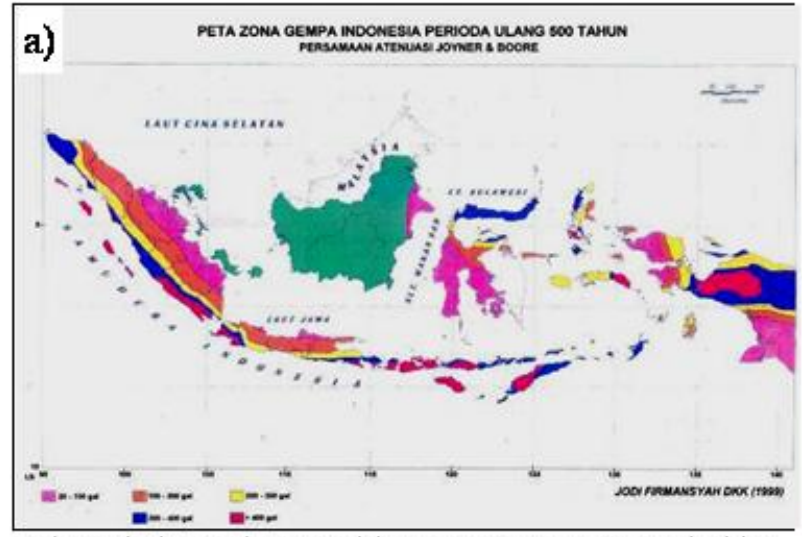

Indonesia hazard map with 500 years retum period by Jodi Firmansyah and Irsyam, ITB.

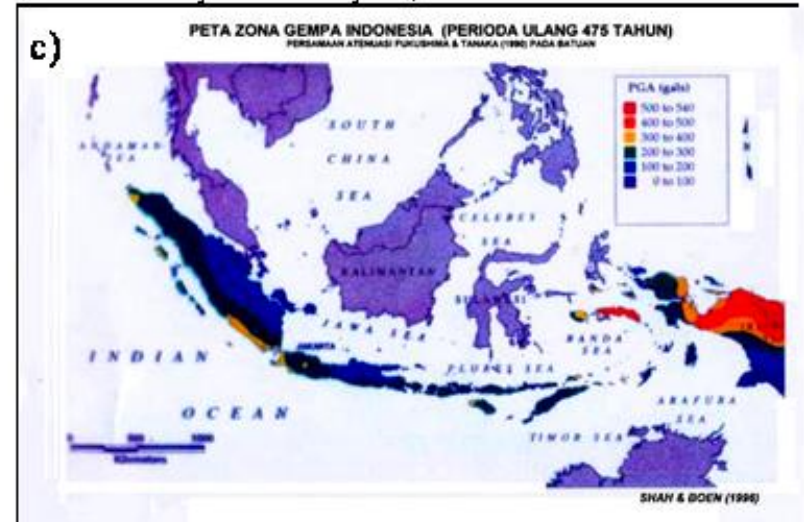

Indonesia hazard map with 500 years retum period by Teddy Boen\&Haresh Shah, university of Stanford.

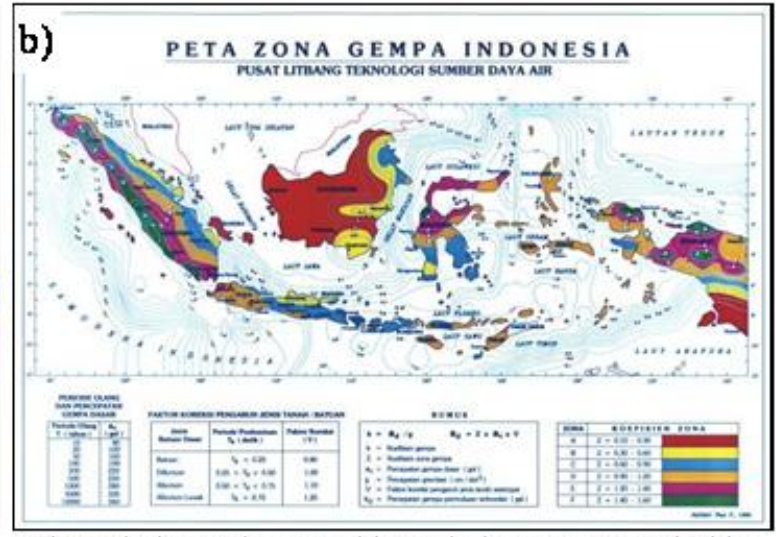

Indonesia hazard map with variation return period by Theo F Najoan, Department of Public Works.

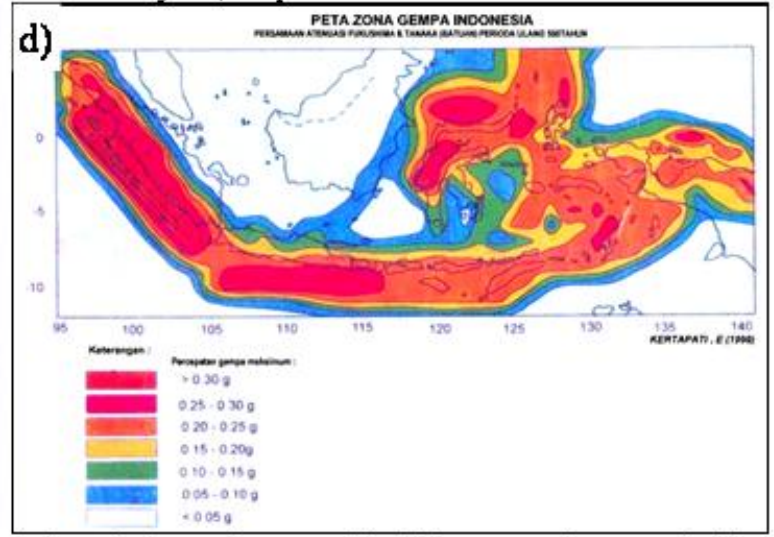

Indonesia hazard map with 500 years retum period by Engkon Kertapati, Dep. Mineral and Energy.

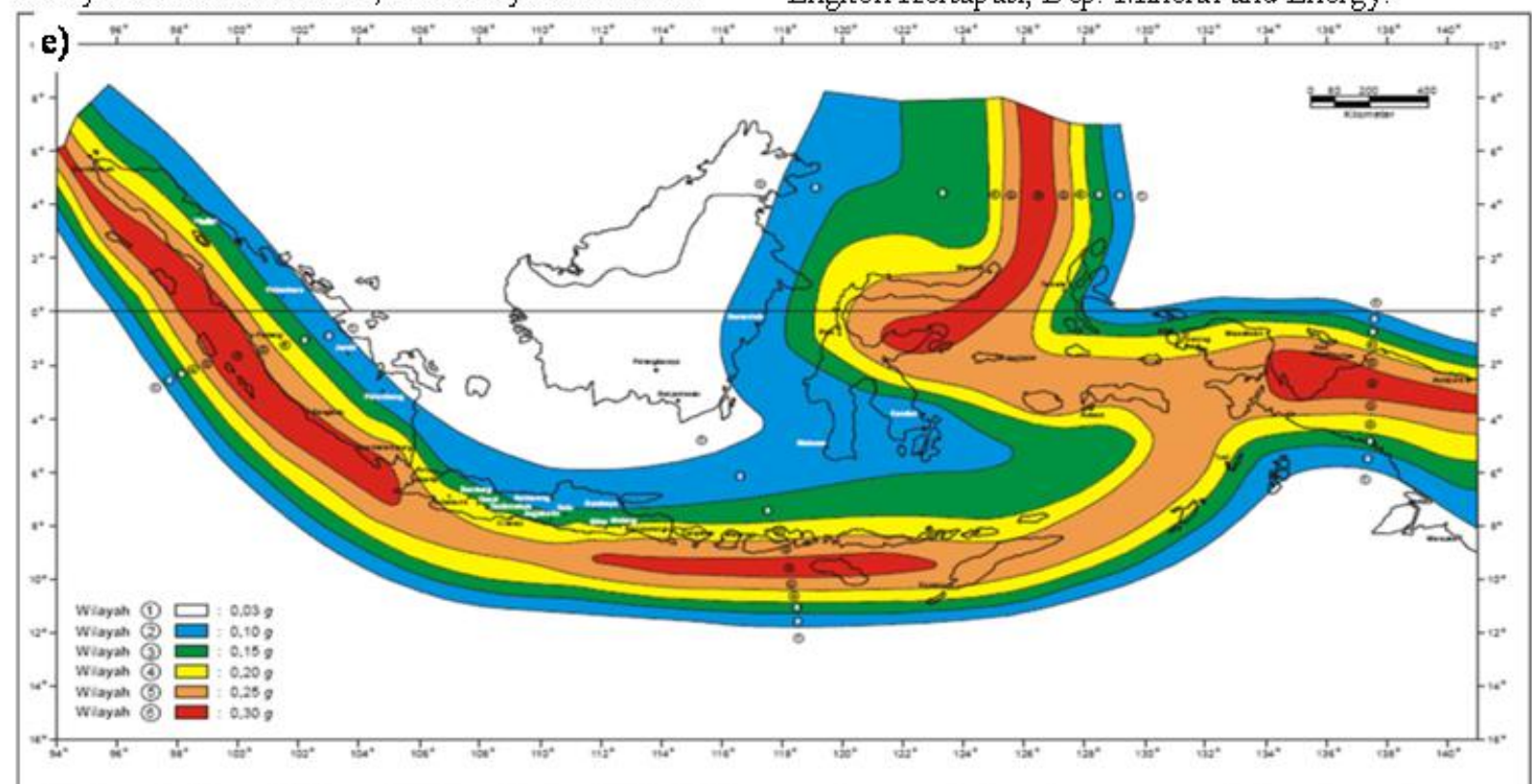

Indonesia Hazard Map of PGA at bedrock for 500 years return period on the average of above hazard map.

Figure 1. Indonesia Hazard Map from four researches and as in SNI 03-1726-2002 [1]. 


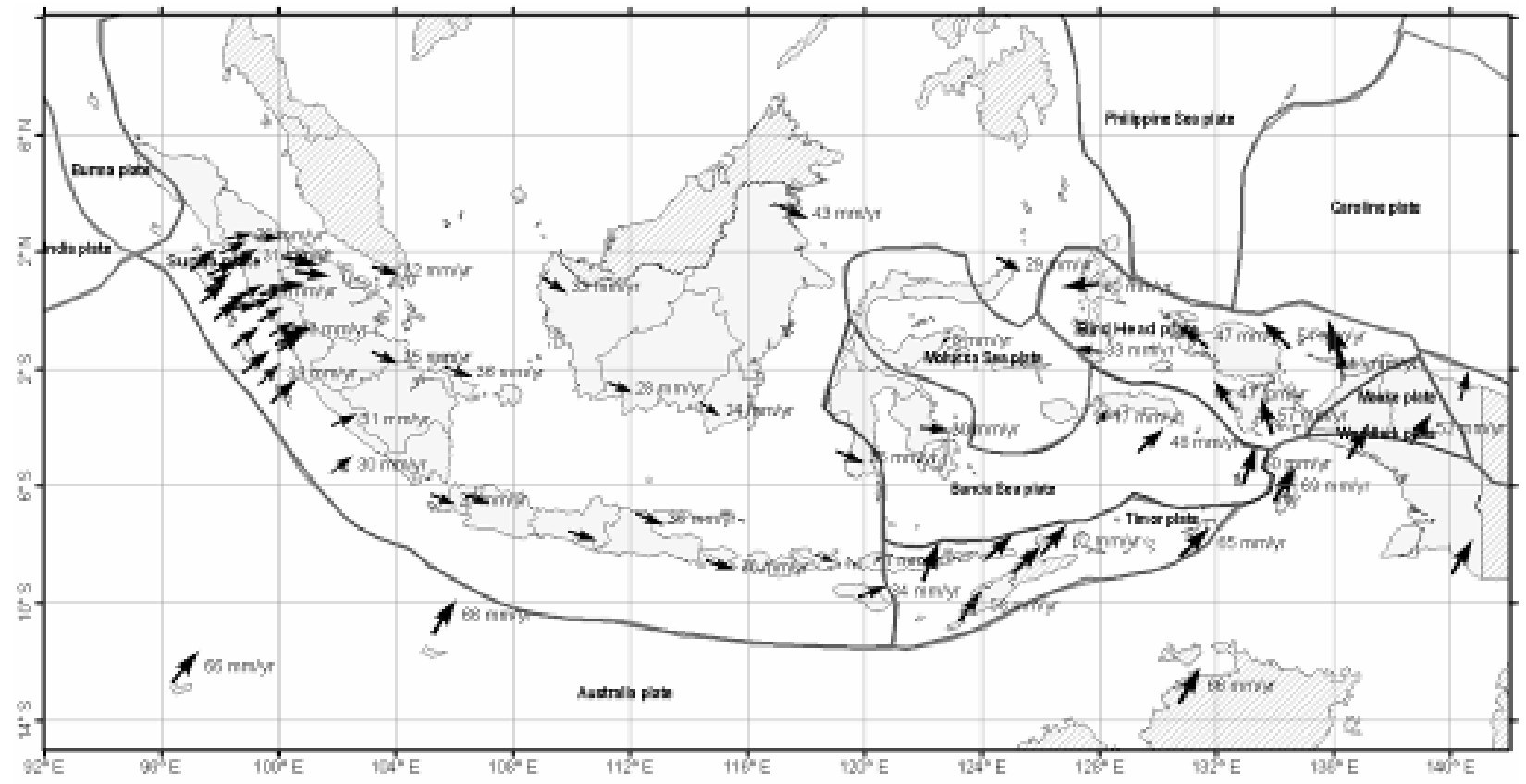

Figure 2.. Mayor tectonic plates of Indonesia region [5] and velocity movement base on GPS from 1991 to 2001 as on ITRF$2000[6]$.

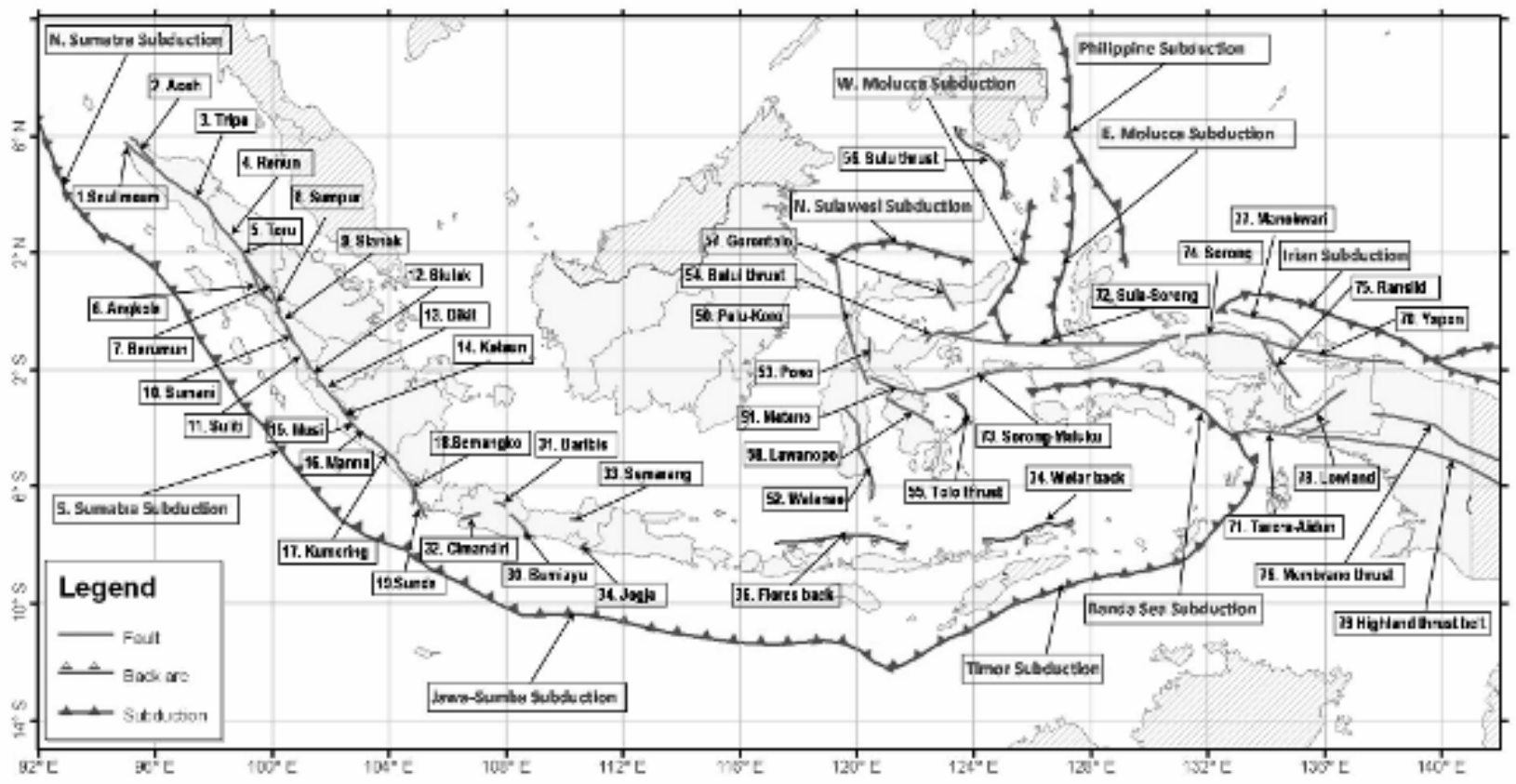

Figure 3. Major tectonic feature Indonesia region (compilation of several researchers).

The perpendicular component is taken up by crustal shortening in the Highlands thrust belt and very likely, subduction along the New Guinea and Manokwari trenches. The margin-parallel component results in left-lateral shear zones along North New Guinea. The existence of subduction zones have created zones of earthquakes that contribute to the event earthquakes occurred in the Indonesian Region.
The magnitude produced by fault movement of this mechanism depends on the area of the fault coupling. There are some potential active faults distributions around Indonesia Islands. The active fault features and parameters used in study based on published reports proposed by several researchers [3, 8-20]. General condition of the mayor tectonic features was shown in Figure 3. 


\section{Seismic Hazard Analysis}

The goal of most seismic hazard modeling is to apply the basic understanding of regional seismic sources in the development of models that capture geologic and seismic event [21]. The process begins with the identification and description of possible earthquake sources, such as active faults or seismic zones. An analysis of past seismic event in the area is conducted to identify patterns, outliers and trends. There are two general approaches for seismic hazard analyses: deterministic seismic hazard analysis (DSHA) and probabilistic seismic hazard analysis (PSHA) [22]. In traditional earthquake engineering, seismic hazard analysis is performed deterministically, considering only a single maximum credible earthquake event. The probabilistic approach is more rational than this worst-case scenario, since it accounts for all possible events (including, of course, the worst expected) that would seismically effects a site.

The method of PSHA was developed by McGuire [23] based on the probability concept developed by Cornell [4], which assumed the earthquake magnitude $\mathrm{M}$ and the hypocenter distance $\mathrm{R}$ as a continuous independent random variable. Although the basic steps of the method remain the same up to today, the models and the computational techniques of the analysis keep being improved as the earth scientists and engineers collect and process more information about earthquakes. The total probability theorem can be represented in the most basic form as follows,

$$
P[I \geq i]=\int_{r} \int_{m} P[I \geq i \mid M \text { and } R] . f_{M}(m) . f_{R}(r) d m d r
$$

Where,

$f_{\mathrm{M}} \quad=$ density function of magnitude

$f_{\mathrm{R}} \quad=$ density function of hypocenter

$P[I \geq i \mid M$ and $R]=\begin{aligned} & \text { distance } \\ & \text { conditional probability of }\end{aligned}$ (random) intensity I exceeding value $i$ at the site for a given earthquake magnitude $\mathrm{M}$ and hypocenter distance $R$.

The analysis is done using the software from the USGS [24]. Site space for analysis used 0.1 degrees of latitude and longitude, so that the calculations of seismic hazard for the Indonesia region are over than 96,600 sites. Results obtain from this form are acceleration at each site, can be used for the development of mapping spectra response on the bedrock. The selected period is PGA, $\mathrm{T}=0.2 \mathrm{sec}$ and $\mathrm{T}=1.0 \mathrm{sec}$, where this period is as in the IBC-2006 [25].

\section{Seismic Source Models}

A seismic source model is defined as a seismically homogenous area, in which every point within the source zone is assumed to have the same probability of being the epicenter of a future earthquake [26]. The Models were developed using earthquake catalogs, tectonic boundaries, and fault information, where composed of background seismicity, fault and subduction sources (Fig. 4) as recently developed by USGS for U.S. hazard map [27].

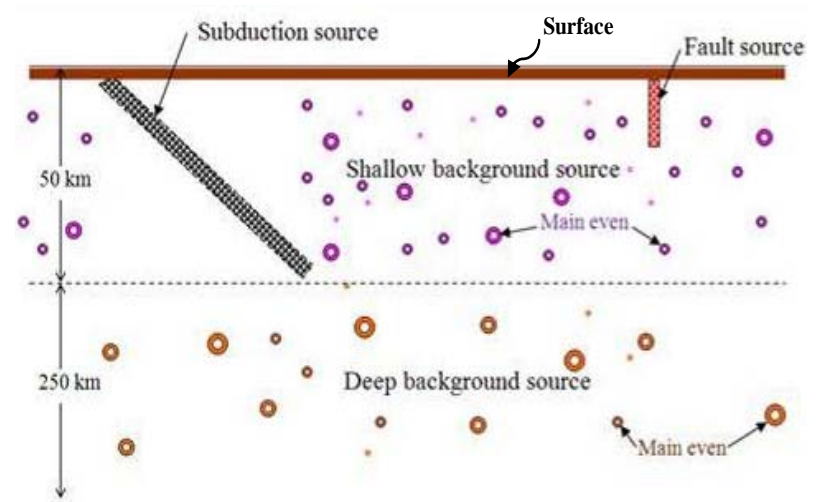

Figure 4. Seismic source model as USGS proposed USGS (illustrated by author).

Background seismicity in the model accounts for random earthquakes on unmapped faults and smaller earthquakes on mapped faults. A type of background seismicity is gridded models that are based on spatially smoothed earthquake rates [28]. Background sources are based on the declustered (dependent event removed) earthquake catalog. This model accounts for the observation that larger earthquakes $(M \geq 5)$ occur near smaller $(M \geq 4$ or 5$)$ earthquakes. Gridded seismicity included in the model is based on earthquakes at five depth intervals: $0-50 \mathrm{~km}$ as shallow source, 50-100 km, 100-150 km, 150-200 km and 200-300 km as deep source model. A truncated-exponential or GutenbergRichter (GR) [29] magnitude-frequency distribution between M 5.0 and M 6.5 is used to model rates for different sizes of earthquakes in each grid cell or zone.

Fault source model is used for well-mapped as geographically and seismologically faults. The length of the mapped fault and downdip width estimated from seismicity may be used to calculate maximum magnitudes of earthquakes expected to occur on these faults [30]. For determining magnitude from fault area or surface length on different segments or multi-segment ruptures the relations of Wells and Coppersmith [30] are used. The major tectonic feature (Figure 3) and sense of faulting, slip-rate, dip, width and maximum magnitude are estimated based on published data.

Subduction source model is the model of the seismic source, which represents the earthquake occurrence when plates are being subducted under an island arc 
or continent. Information used as input parameters of this model include the location of subduction in the latitude and longitude coordinates, rate and b-value of the subduction area that can be obtained from the historical earthquake data with least square (GR) method [29]. This model was Limited to $50 \mathrm{~km}$ depth of the source rupture or Megathrust zones, deeper zones or Benioff zones are represented by deep background source models.

\section{Recurrence relations}

Recurrence relations are the means of defining the relative distribution of large and small magnitude and incorporating the seismic history into the hazard analysis. On the basis of worldwide seismicity catalog, Gutenberg-Richter [29] established the loglinear relation given by Equation (2). This relation has been assumed to apply to individual areal and fault sources as well. One of the steps in characterizing seismic sources is the assignment of a maximum magnitude to each source. This requires the GR line to taper into the maximum value as shown in Figure 5.a. This distribution is called the truncated exponential and is given in exponential form in Equation (3).

$$
\log N(M)=a-b M
$$

Where $N(M)$ is the number of earthquakes per year with a magnitude equal to or greater than $\mathrm{M}$ and $a$ and $b$ are constants for the seismic zone. $\mathrm{N}$ is associated with a given area and time period.

$$
N(M)=\left[\beta \exp \left(-\beta\left(M-M_{\min }\right)\right)\right] /\left[1-\exp \left(-\beta\left(M_{\max }-M_{\min }\right)\right)\right](3)
$$

Where $M_{\max }$ is the assigned maximum magnitude,
$M_{\min }$ is the smallest earthquake that needs to be considered, $\beta=b \ln (10)$ and $b$ is the slope of the GR line in Figure 5a. Source specific values of $b$ are used in this equation.

The truncated exponential model is used for shallow and deep background sources with weighting of 1.0. Fault segments tend to have occurrences of earthquakes of similar size or within a narrow range of magnitudes. These earthquakes are called characteristic earthquakes. Typically smaller earthquakes on the fault follow the GR line and the characteristic earthquakes occur at higher rates. So for fault and subduction sources both truncated exponential (GR) and characteristic models (char) are used with a weighting of 0.34 and 0.66, respectively A characteristic model is used following Youngs and Coppersmith [31] shown in Figure 5b.

Determining the maximum magnitude in seismic source model for the hazard analyses is important. There are two ways in determining the maximum magnitude. The first is determined from historical earthquake, and second is determined at the zones where only few historical earthquake data but the fault system that have potential for the occurance of big earthquake magnitude, so that the value of the maximum magnitude can be taken using the equation proposed Wells \& Coppersmith [30].

\section{Data Collection and Processing}

The analysis of seismic hazard assessment at the site of interest needs all data that record the earthquake event occurred in that site for a specific a)

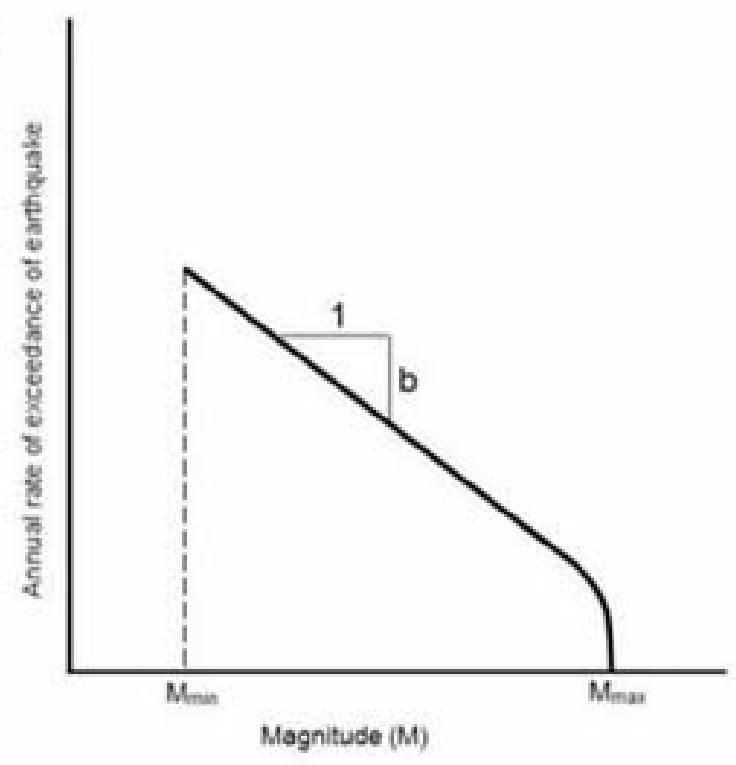

b)

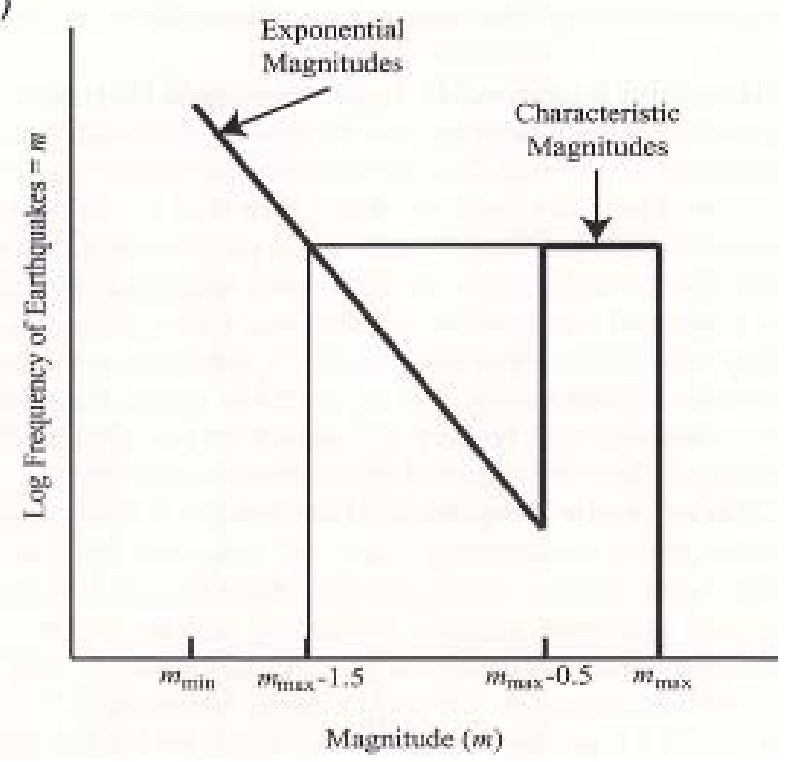

Figure 5. a)Truncated exponential distribution of recurrence rates, b) Characteristic earthquake occurrence model after Schwartz and Coppersmith [31] 
time period of observation. In this study, historical earthquake event is compiled from many sources, such as:

- Earthquake listings held by the National Earth quake Information Service U.S. Geological Survey (NEIS-USGS) of the United States, which is a compilation of several catalogs from sources such as: The Bureau Central International de Séismologie (BCIS), the International Seismological Summaries (ISS), the International Seismological Center (ISC), the Preliminary Determination of Epicenters (PDE), and The Advanced National Seismic System (ANSS) catalog.

- Indonesia earthquake listing prepared by the Bureau of Meteorology and Geophysics (BMG), Jakarta, Indonesia.

- Centennial Catalog which is compiled from Abe, Abe \& Noguchi, Newcomb \& McCann catalog [32], where several large event in Indonesia have been relocated and Pacheco \& Sykes catalog [33], where the earthquakes were corrected for heterogeneity's caused presumably by changes in instrumentation, reporting and/or detection capabilities.

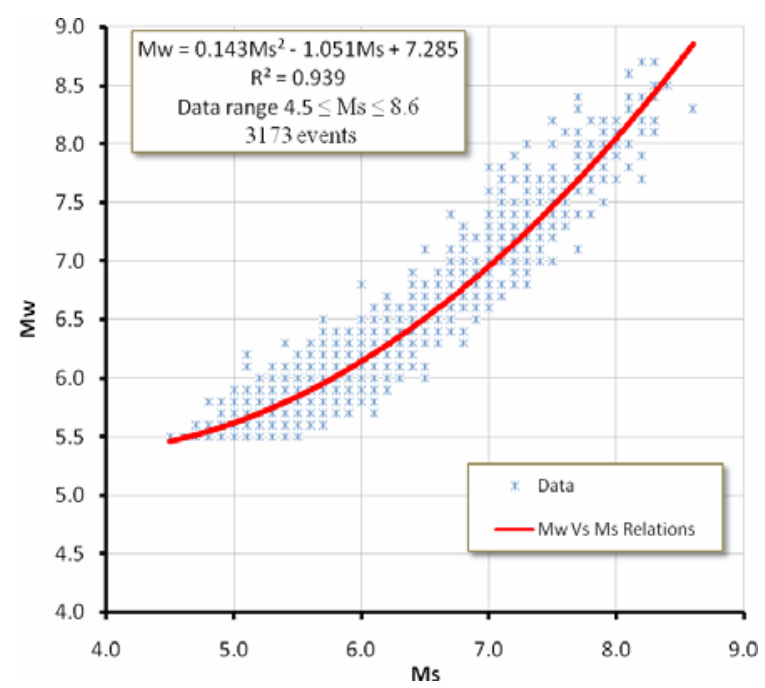

Period of data from 1900 to 2007, but the annual rate for the analysis uses data from 1964 to 2007. The catalogs from various sources generally have varied magnitude scale. The varied magnitude should be converted into one same scale before it is uses in PSHA. Magnitude scale like surface wave magnitude (Ms), local Richter magnitude (ML), and body wave magnitude (mb) is converted to the moment magnitude (Mw). The analysis of conversion in this study uses earthquake catalog of Indonesia region that is collected from various sources as mentioned above. Using regression analysis (Figure 6) correlation formula for the conversion magnitude scale for Indonesia region, is obtained as seen in Table 1.

PSHA is based on independent earthquake (mainshock) event. Several empirical criteria to identify dependent event developed based on a range of time and a specified distance from a large earthquake occurrence have been made by some researchers as Arabasz \& Robinson [34], Garner \& Knopoff [35] and Uhrhammer [36]. Shorting dependency result using Garner \& Knopoff [35] can be seen in Figure 7.

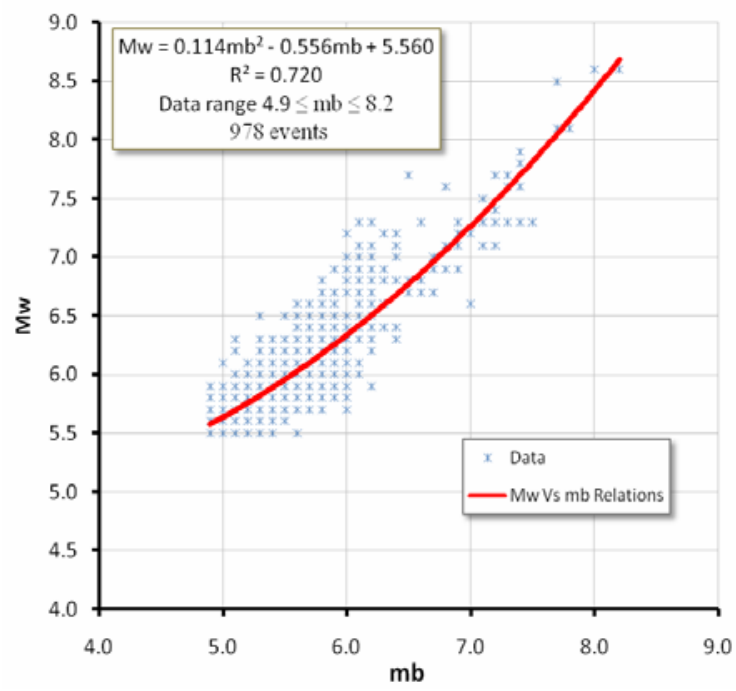

Figure 6. Magnitude scale corelation chart from earthquake catalog Indonesia region.

Table 1: Convertion corelation formula several magnitude scale for Indonesia region.

\begin{tabular}{lccc}
\hline \multicolumn{1}{c}{ Convertion corelation } & Number of Data & Range of Mag & Consistency $\left(\mathbf{R}^{2}\right)$ \\
\hline $\mathrm{M}_{\mathrm{w}}=0.143 \mathrm{M}_{\mathrm{s}}^{2}-1.051 \mathrm{M}_{\mathrm{s}}+7.285$ & 3.173 & $4.5 \leq \mathrm{Ms}_{\mathrm{s}} \leq 8.6$ & $93.9 \%$ \\
$\mathrm{M}_{\mathrm{w}}=0.114 \mathrm{mb}^{2}-0.556 \mathrm{mb}+5.560$ & 978 & $4.9 \leq \mathrm{mb} \leq 8.2$ & $72.0 \%$ \\
$\mathrm{M}_{\mathrm{w}}=0.787 \mathrm{M}_{\mathrm{E}}+1.537$ & 154 & $5.2 \leq \mathrm{M}_{\mathrm{E}} \leq 7.3$ & $71.2 \%$ \\
$\mathrm{mb}=0.125 \mathrm{M}_{\mathrm{L}}^{2}-0.389 \mathrm{x}+3.513$ & 722 & $3.0<\mathrm{M}_{\mathrm{L}}<6.2$ & $56.1 \%$ \\
\hline
\end{tabular}




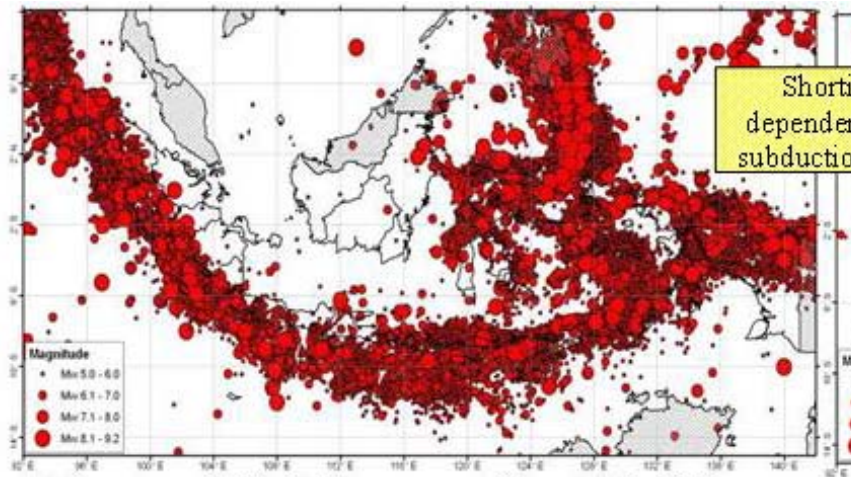

(a) Epicentre of all shallow event $(0-50 \mathrm{~km})$ from 1900 to 2007

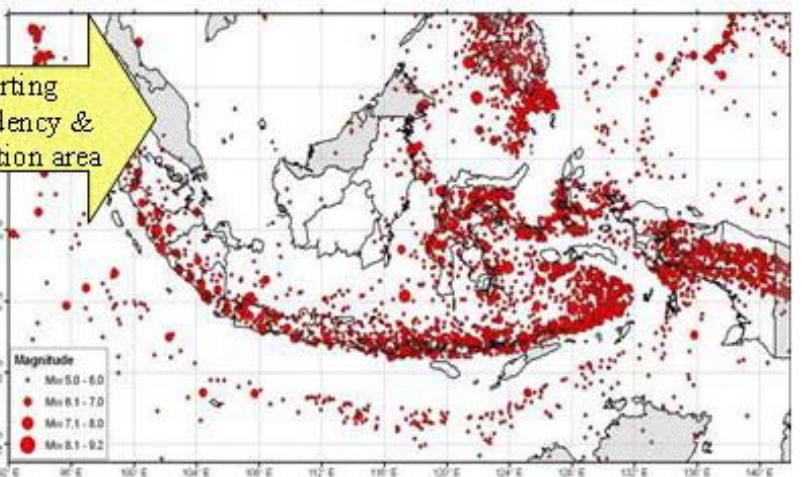

(b) Epicentre of shallow main event $(0-50 \mathrm{~km})$

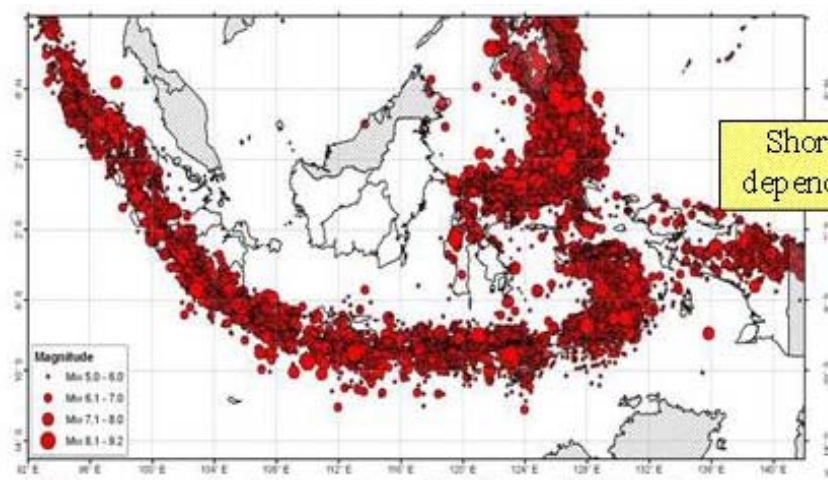

(c) Epicentre of all deep event (50-300 km) from 1900 to 2007

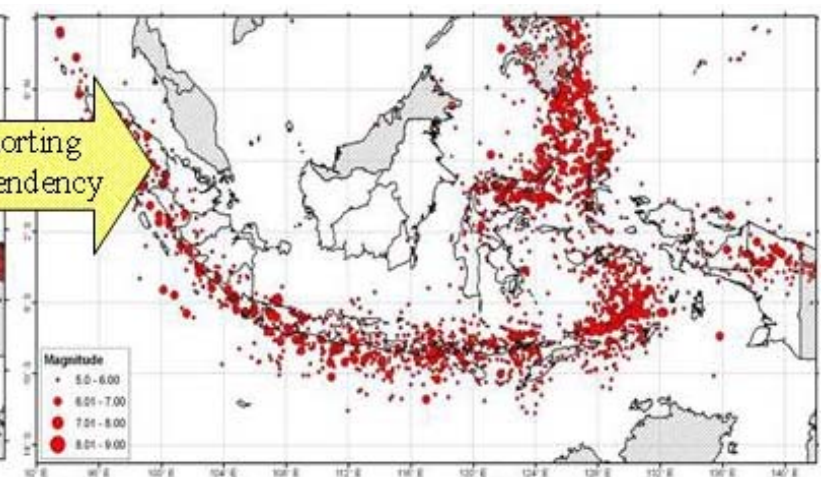

(d) Epicentre of deep main event $(0-50 \mathrm{~km})$

Figure7. Shorting dependency earthquakes catalog Indonesia region

\section{Attenuation}

Attenuation relations tend to be regionally specific, unfortunately there is no attenuation specifically developed for Indonesia region. The only way is to adapt attenuation function derived in other region, which is similar to Indonesia region tectonically and geologically. It is of importance that the selection was based on earthquake mechanism, which is generally categorized into background, fault and subduction source zones. Some attenuation relationships have used Next Generation Attenuation (NGA) as listed:

a) Attenuation for Shallow Background.
1) Boore-Atkinson NGA [37].
2) Campbell-Bozorgnia NGA [38].
3) Chiou-Young NGA [39].

b) Attenuation for Deep Background Sources.

1) Atkinson-Boore intraslab Puget Sound region BC-rock condition [40].

2) Geomatrix slab seismicity rock [41].

3) Atkinson-Boore intraslab seismicity world data BC-rock condition [42].

c) Attenuation for Fault Sources.

1) Boore-Atkinson NGA [37].

2) Campbell-Bozorgnia NGA [38].

3) Chiou-Young NGA [39]. d) Attenuation for Subduction Sources.

1) Geomatrix subduction [41].

2) Atkinson-Boore BC rock and global Source [42].

3) Zhao et al., with variable $V_{\mathrm{s}-30}$ [43].

Logic-tree by Power et. al. [44]; Kulkarni et al. [45]; Coppersmith and Youngs [46] is used in this study in order to allow uncertainties in selection of models for recurrence model, maximum magnitude and attenuation function to be considered. The weighting of logic tree used in the analysis can be seen in Table $2 \mathrm{a}$ and $2 \mathrm{~b}$.

\section{Result and Discussion}

Spectral hazard analysis on this study uses shallow background, deep background, fault and subduction seismic source models as recently developed by USGS for U.S. hazard map [27].

Hazard maps of PGA at bedrock with 5\% damping and spectral acceleration at 0.2 , and $1.0 \mathrm{sec}$ with $2 \%$ probability of exceedance in 50 years or equivalent to 2500 year return period are shown in Figures 8 to 10. respectively. 
Tabel 2a. Logic tree weighting for shallow and deep background sources.

\begin{tabular}{|c|c|c|c|c|}
\hline Recurrence & $\mathbf{M}_{\min }$ & $\mathbf{M}_{\max }$ & Mechanism & Attenuation \\
\hline Shallow background & & & Strike slip (0.5) & Boore-Atkinson NGA, $2008(1 / 3)$ \\
\hline$(\mathrm{GR})$ & 5 & 6.5 & Reverse $(0.25)$ & Campbell-Bozorgnia NGA, $2008(1 / 3)$ \\
\hline (1) & & & Normal (0.25) & Chiou-Young NGA 2008 (1/3) \\
\hline Deep background & & & Strike slip (0.5) & Atkinson-Boore intraslab $2003(1 / 3)$ \\
\hline$(\mathrm{GR})$ & 5 & 7.8 & Reverse $(0.25)$ & Youngs et al, $1997(1 / 3)$ \\
\hline$(1)$ & & & Normal $(0.25)$ & Atkinson-Boore BC-rock, 1995 (1/3) \\
\hline
\end{tabular}

Tabel 2b. Logic tree weighting for fault and subduction sources.

\begin{tabular}{clll}
\hline Recurrence & $\mathbf{M}_{\min }$ & \multicolumn{1}{c}{$\mathbf{M}_{\max }$} & \multicolumn{1}{c}{ Attenuation } \\
\hline Fault & & $\mathrm{M}_{\max }-0.2(0.2)$ & Boore-Atkinson NGA, 2008 (1/3) \\
(GR) & 6.5 & $\mathrm{M}_{\max }(0.6)$ & Campbell-Bozorgnia NGA, 2008 (1/3) \\
$(0.34)$ & & $\mathrm{M}_{\max }+0.2(0.2)$ & Chiou-Young NGA 2008 (1/3) \\
Fault & & $\mathrm{M}_{\max }-0.2(0.2)$ & Boore-Atkinson NGA, 2008 (1/3) \\
(Char) & - & $\mathrm{M}_{\max }(0.6)$ & Campbell-Bozorgnia NGA, 2008 (1/3) \\
$(0.66)$ & & $\mathrm{M}_{\max }+0.2(0.2)$ & Chiou-Young NGA 2008 (1/3) \\
Subduction & & $\mathrm{M}_{\max }-0.2(0.2)$ & Youngs et al., 1997 (1/3) \\
(GR) & 7.1 & $\mathrm{M}_{\max }(0.6)$ & Atkinson-Boore BC rock, 2003 (1/3) \\
$(0.34)$ & & $\mathrm{M}_{\max }+0.2(0.2)$ & Zhao et al., 2006 (1/3) \\
Subduction (Char) & & $\mathrm{M}_{\max }-0.2(0.2)$ & Youngs et al., 1997 (1/3) \\
$(0.66)$ & - & $\mathrm{M}_{\max }(0.6)$ & Atkinson-Boore BC rock, 2003 (1/3) \\
& & $\mathrm{M}_{\max }+0.2(0.2)$ & Zhao et al., 2006 (1/3) \\
\hline
\end{tabular}

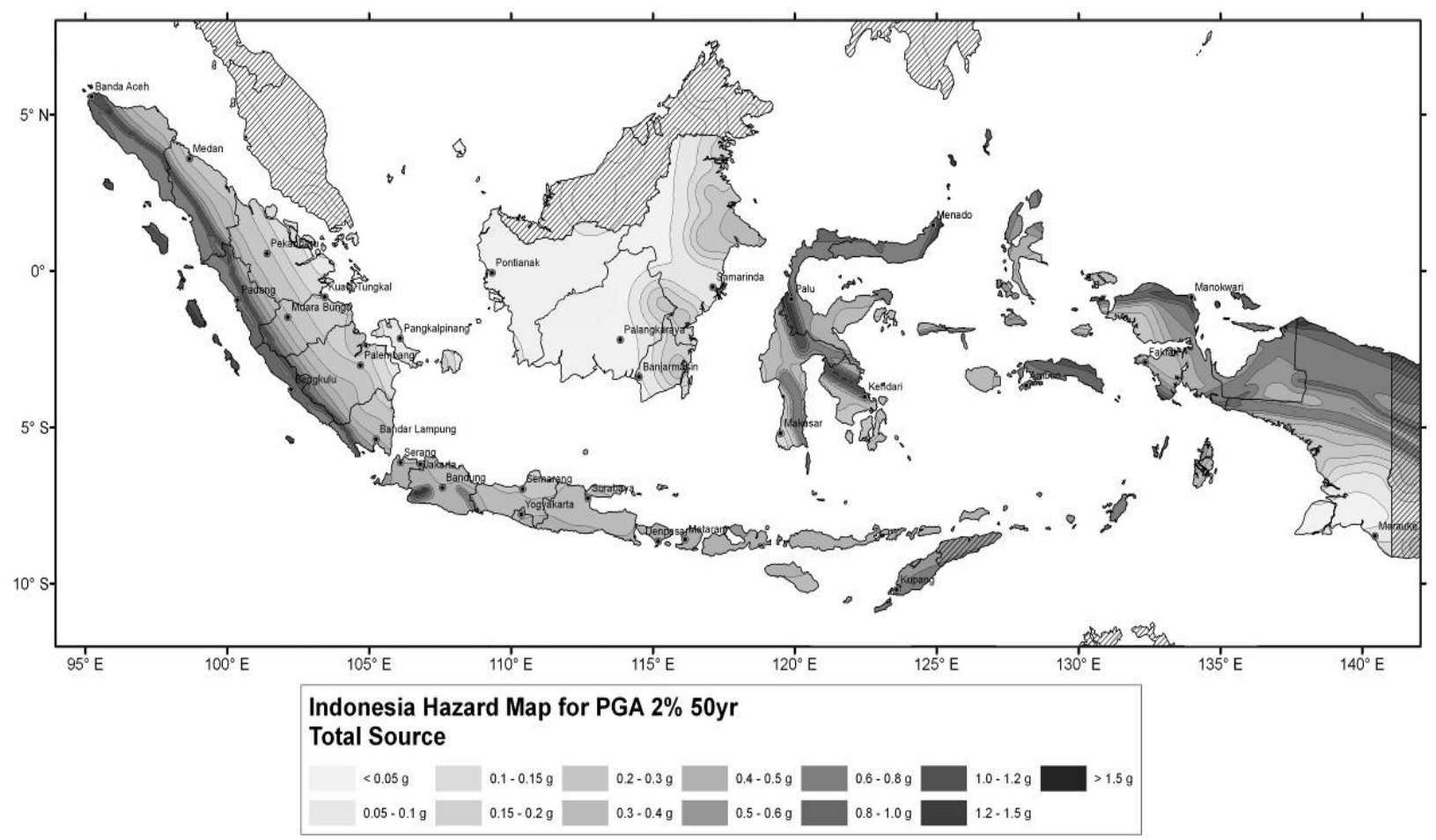

Figure 8. Map of Peak Ground Acceleration (PGA) of Indonesia for 2\% probability of exceedance in 50 years (2500 years return period of earthquake) 


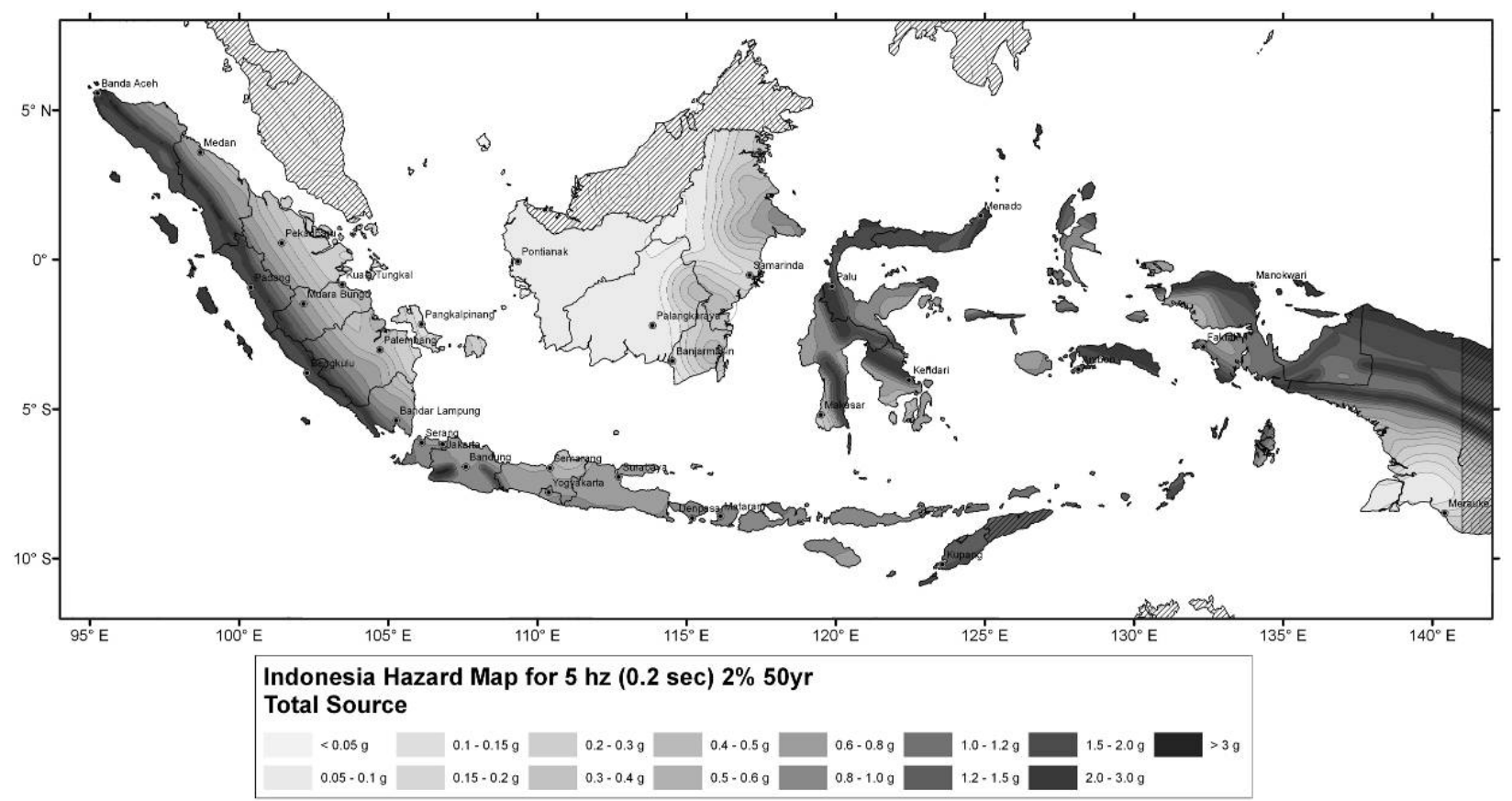

Figure 9. Map of $0.20 \mathrm{sec}$ spectral acceleration of Indonesia for $2 \%$ probability of exceedance in 50 years (2500 years return period)

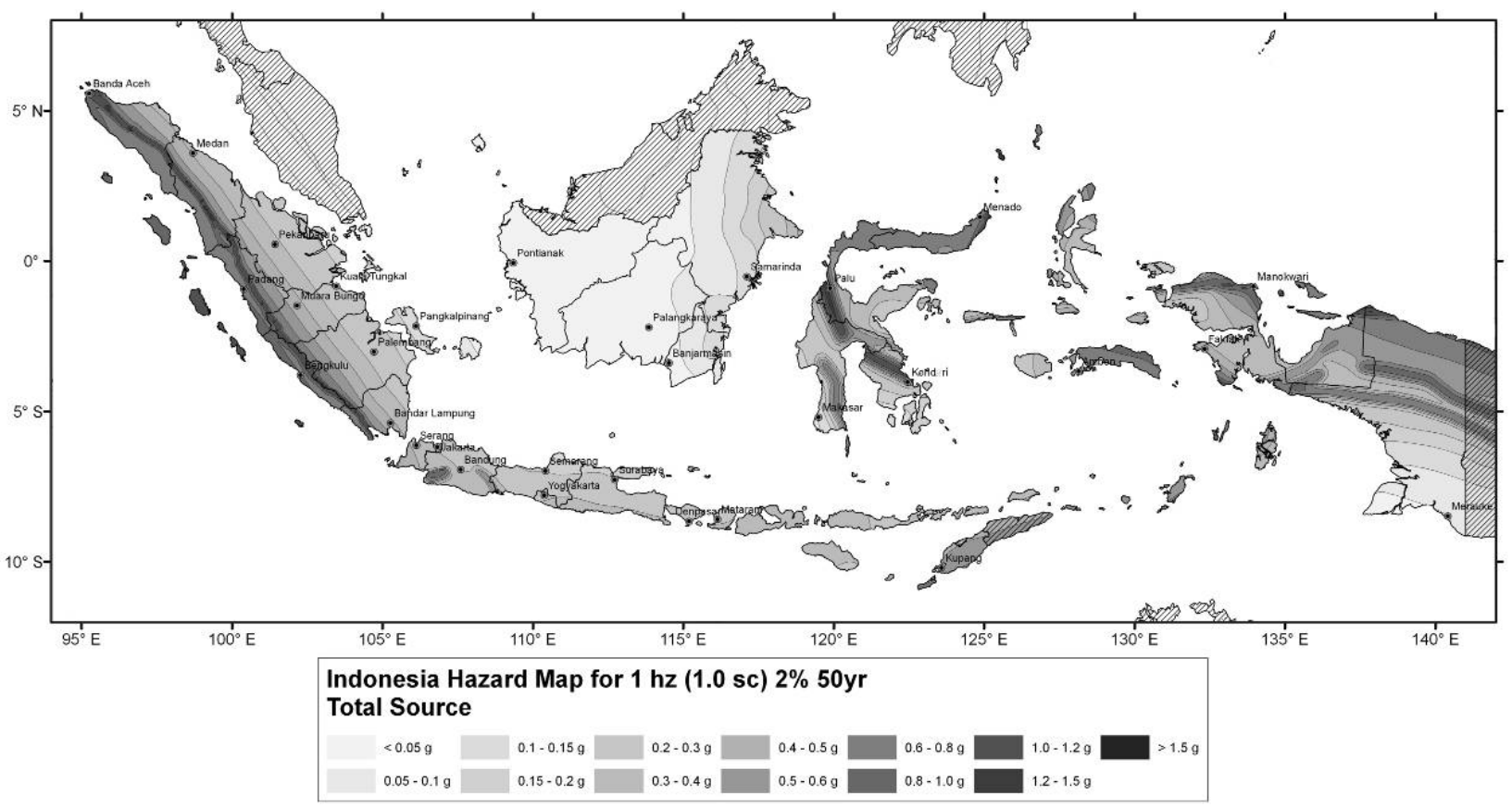

Figure 10. Map of $1.0 \mathrm{sec}$ spectral acceleration of Indonesia for $2 \%$ probability of exceedance in 50 years (2500 years return period).

In general, the results of seismic hazard expressed significantly higher on the active fault compared to the SNI 03-1726-2002.

The hazard value for PGA on bedrock in 2500 years return period ( $2 \%$ probability exceeded in 50 years) is about 1.2 - 3 times of the value of the SNI 03-17262002 (Figure 1). The increase of hazard values is affected by the increase of maximum magnitudes and other input parameters and by utilizing 3-D earthquake source model not to speak of 2500 and 500 years return period.

The spectral hazard map developed in this study will be proposed as a revision for the current seismic hazard map of Indonesia in Indonesian Seismic 
Building Code SNI-03-1726-2002 especially for maximum credible earthquake magnitude (MCE) design.

\section{Acknowledgments}

The authors gratefully acknowledge Mark Petersen and Stephen Harmsen, both from the USGS, who have provided us with the USGS Software for Probabilistic Seismic Hazard Analysis and technical discussions.

\section{References}

1 SNI 03-1726-2002, Tata Cara Perencanaan Ketahanan Gempa untuk Bangunan Gedung, Badan Standarisasi Nasional, Jakarta, 2002.

2 Najoan, T.F., Djanasoedirdja, S., Ruhijat, S., Peta Zona Gempa Hasil Tinjauan Ulang dan Cara Penggunaannya Sebagai Usulan dalam Perencanaan Bangunan Pengairan Tahan Gempa, Jurnal Puslitbang Pengairan, Vol. 36, Th.11-KW. I, 1995, pp. 22-36.

3 SNI 2833:2008, Standar Perencanaan Ketahanan Gempa untuk Jembatan, ICS 91.120.25, Badan Standarisasi Nasional, 2008.

4 Cornell, C.A., Engineering Seismic Risk Analysis, Bull. Seismol. Soc. Am., Vol. 58. 1968, pp. 15831606.

5 Bird, P., An Updated Digital Model of Plate Boundaries, Geochemistry, Geophysics, Geosystems, Vol. 4, no. 3, 1027, 2003. doi: 0.1029/ $2001 \mathrm{GC} 000252$.

6 Bock, Y., Prawirodirdjo, L., Genrich, J.F., Stevens, C.W., McCaffrey, R., Subarya, C., Puntodewo, S.S.O., and Calais, E., Crustal Motion in Indonesia from Global Positioning System Measurements, J. Geophys. Res., Vol. 108, no. B8, 2367, 2003, doi: 0.1029/ 2001JB000324.

7 McCaffrey, R., Slip Vectors and Stretching of the Sumatran Fore Arc, Geology, 19(9), 1991, pp. 881- 884 .

8 Sieh, K., Natawidjaja, D., Neotectonics of the Sumatran Fault, Indonesia. J. Geophys. Res., Vol. 105, 2000, pp. 28295-28326.

9 Katili, J., Past and Present Geotectonic Position of Sulawesi, Indonesia. Tectonophysics 45, 1978, 289-32.

10 Socquet, A., Vigny, C., Chamot-Rooke, N., Simons, W., Rangin, C., and Ambrosius, B., India and Sunda plates motion and deformation along their boundary in Myanmar determined by GPS: J. Geophys. Res., Vol. 111, B05406, 2006, doi: 0.1029/2005JB003877.
11 Parkinson, C.D., Emplacement of the East Sulawesi Ophiolite: Evidence from Subophiolite Metamorphic rocks, J. SE Asian Earth Sci., 6 (1), 1998, pp. 1-16.

12 Hall, R, \&, Wilson, M.E.J., Neogene Sutures in Eastern Indonesia, J. SE Asian Earth Sci., 18, 2000, pp. 781-808.

13 Silver, E.A., Reed, D., McCaffrey, R., Back Arc Thrusting in the Eastern Sunda Arc, Indonesia: A Consequence of Arc Continent Collisin, $J$. Geophys. Res., Vol. 88, no. B9, 1983, pp. 74297448.

14 Réhault J.P., Malod J.A., Larue M., Burhanuddin S., Sarmili L., A New Sketch of the Central North Banda Sea, Eastern Indonesia, $J$. SE Asian Earth Sci., 6 (3-4), 1991, pp. 329-334.

15 Shah, H.C. and Boen, T., Seismic Hazard Model for Indonesia, Unpublished Paper, April 1996.

16 Lasitha, S., Radhakrishna, M., and Sanu, T.D., Seismically Active Deformation in the SumatraJava Trench-arc Region: Geodynamic Implications, Current Science, Vol. 90, no. 5, 10 March 2006.

17 McCaffrey, R., and Nabelek, J., Earthquakes, Gravity and Origin of the Bali Basin: An Example of a Nascent Continental Fold-andthrust Belt, J. Geophys. Res., Vol. 92, 1987, pp. 441-460.

18 Hall, R., Extension During Late Neogene Collision in East Indonesia and New Guinea, Journal of the Virtual Explorer, ISSN 1441-8126 Volume No. 4, 2001.

19 Visser, W.A. and Hermes, J.J., Geological Results of the Exploration for Oil in the Netherlands New Guinea, Verh. K., Ned. Geol. Mijnbouw, Genoot, 20, 1962, pp. 1-265.

20 Hamilton, W., Tectonic Map of the Indonesia Region, United States Geological Survey Map 1875-D, 1978.

21 Reiter, L., Earthquake Hazard Analysis: Issues and Insights, Columbia University Press, New York, 1990.

22 Irsyam, M., Dangkua, D.T., Kusumastuti, D., Kertapati, E.K., Methodology of Site-Specific Seismic Hazard Analysis for Important Civil Structure, Civil Engineering Dimension, Vol. 9, no. 2, 2007, pp. 103-112.

23 McGuire, R.K., Probabilistic Seismic Hazard Analysis and Design Earthquakes: Closing the Loop, Bull. Seismol. Soc. Am., Vol. 85, no. 5, 1995, pp. 1275-1284.

24 Harmsen, S., USGS Software for Probabilistic Seismic Hazard Analysis (PSHA), Draft 
Document, (unpublished, received by hand), 2007.

25 International Building Code (IBC), International Code Council, Chapter 16 Structural Design, 2006.

26 Erdik, M., Doyuran, V., Yucemen, S., Gulkan, P., and Akkas N., A Probabilistic Assessment of the Seismic Hazard in Turkey for Long Return Periods, Proc. 3rd International Earthquake Microzonation Conference, Seattle, Washington, 1982.

27 Petersen M.D., Frankel, A.D., Harmsen, S.C., Mueller, C.S., Haller, K.M., Wheeler, R.L., Wesson, R.L., Zeng, Y., Boyd, O.S., Perkins, D.M., Luco, N., Field, E.H., Wills, C.J. and Rukstales, K.S., Documentation for the 2008 Update of the United States National Seismic Hazard Map, USGS Open-File Report 20081128.

28 Frankel, A., Mapping Seismic Hazard in the Central and Eastern United States, Seismological Research Letters, Vol. 66, no.4, 1995, pp. 821.

29 Gutenberg, B. and Richter, C., Frequency of Earhquakes in California, Bull. Seismol. Soc. Am., Vol. 34, 1944, pp. 185-188.

30 Wells, D.L. and Coppersmith, K.J., New Empirical Relationships among Magnitude, Rupture Length, Rupture Width, Rupture Area, and Surface Displacement, Bull. Seismol. Soc. Am., 84(4), 1994, pp. 974-1002.

31 Schwartz, D.P. and Coppersmith, K.J., Fault Behavior and Characteristic EarthquakesExamples from the Wasatch and San Andreas Fault Zones, J. Geophys. Res., Vol. 89, no. B7, 1984, pp. 5681-5698.

32 Newcomb, K.R. and McCann, W.R., Seismic History and Seismotectonics of the Sunda Arc, J. Geophys. Res., Vol. 92, 1987, pp. 421-439.

33 Pacheco, J.F. and Sykes, L.R., Seismic Moment Catalog of Large Shallow Earthquakes, 1900 to 1989, Bull. Seismol. Soc. Am., Vol. 82, 1992, pp. 1306-1349.

34 Arabasz, W.J. and Robinson, R., Microseismicity and Geologic Structure in the Northern South Island, New Zealand, New Zealand Journal of Geology and Geophysics, Vol. 19, no. 2, 1976, pp. 561-1367.

35 Gardner, J.K. and Knopoff, L., Is the Sequence of Earthquakes in Southern California, with Aftershocks Removed, Poissonian?, Bull. Seismol. Soc. Am., Vol. 64, 1974, pp. 1363-1367.
36 Uhrhammer, R.A., Characteristics of Northern and Central California Seismicity, Earthquake Notes, Vol. 57, No. 1, 1986.

37 Boore, D.M. and Atkinson, G.M., Ground-motion Prediction Equations for the Average Horizontal Component of PGA, PGV, and 5\%-damped PSA at Spectral Periods between $0.01 \mathrm{~s}$ and $10.0 \mathrm{~s}$, Earthquake Spectra, Vol. 24, no. 1. 2008.

38 Campbell, K.W. and Bozorgnia, Y., Ground Motion Model for the Geometric Mean Horizontal Component of PGA, PGV, PGD and 5\%-damped Linear Elastic Response Spectra for Periods Ranging from 0.01 to $10.0 \mathrm{~s}$, Earthquake Spectra, Vol. 24, no. 1, 2008.

39 Chiou, B. and Youngs, R., A NGA Model for the Average Horizontal Component of Peak Ground Motion and Response Spectra, Earthquake Spectra, Vol. 24, no. 1, 2008.

40 Atkinson, G., Boore, D., New Ground Motion Relations for Eastern North America, Bull. Seismol. Soc. Am., Vol. 85, 1995, pp. 17-30.

41 Youngs, R.R., Chiou, S.J., Silva, W.J., Humphrey, J.R., Strong Ground Motion Attenuation Relationships for Subduction Zone Earthquakes, Seismol. Res. Lett., Vol. 68, 1997, pp. 58-73.

42 Atkinson, G.M., Boore, D.M, Empirical GroundMotion Relations for Subduction Zone Earthquakes and Their Application to Cascadia and Other Regions, Bull. Seismol. Soc. Am., Vol. 93, no. 4, 2003, pp. 1703-1729.

43 Zhao John, X., Zhang, J., Asano, A., Ohno, Y., Oouchi, T., Takahashi, T., Ogawa, H., Irikura, K., Thio, H., Somerville, P., Attenuation Relations of Strong Motion in Japan using Site Classification Based on Predominant Period, Bull. Seismol. Soc. Am., Vol. 96, 2006, pp. 898.

44 Power, M.S., Coppersmith, K.J., Youngs, R.R., Schwartz, D.P., Swan, R.H., Seismic Exposure Analysis for the WNP-2 and WNP-1/4 Site: Appendix 2.5K to Amendment no. 18 Final Safety Analysis Report for WNP-2, WoodwardClyde Consultants, 1981.

45 Kulkarni, R.B., Youngs, R.R., and Coppersmith, K.J., Assessment of Confidence Interval for Results of Seismic Hazard Analysis, Proceedings, 8th World Conference on Earthquake Engineering, San Fransisco, Vol. 1, 1984.

46 Coppersmith, K.J., Youngs, R.R., Capturing Uncertainty in Probabilistic Seismic Hazard Assessment with Intraplate Tectonic Environments, Proceedings, 3rd U. S. National Conference on Earthquake Engineering, Charleston, South Carolina, Vol. 1, 1986, pp.301-312. 